\title{
Housing Affordability Problems among Young Households
}

\author{
${ }^{1}$ Zafirah Al Sadat Zyed, ${ }^{2}$ Wan Nor Azriyati Wan Abd Aziz, ${ }^{3}$ Noor Rosly Hanif \\ Department of Estate Management, Faculty of Built Environment, University of Malaya \\ $\underline{{ }^{1} \text { zafirahzyed@um.edu.my }} \underline{{ }^{2} \text { wyati@um.edu.my }} \underline{\text { 3nroslyhanif@um.edu.my }}$
}

\begin{abstract}
Young households are facing various challenges especially as a new entrant in the employment sector. More specifically, there have been worries that young households may not be able to afford a house due to the increasing house prices and cost of living. The aim of this paper is to ascertain the housing affordability problems among young households in Greater Kuala Lumpur. The aim is supported with two objectives which are to identify the housing affordability problems among young households and to discuss the relationship between the identified problems. This paper adopts the case study method and Greater Kuala Lumpur is chosen as the location of the case study. This paper concludes that the main problem faced by young households is limited supply of affordable housing in the market. Even more, the perceived affordable housing in the market is open to all income groups which suggest that young households has to compete with other income groups in the market for homeownership.
\end{abstract}

Keywords: housing; young households; housing affordability; housing problems; housing policy

\section{HOUSING AFFORDABILITY PROBLEMS AND YOUNG HOUSEHOLD}

Young households who have graduated and secure employment have set their sights on affordable housing. The problem of providing affordable housing is not new. However, the provision of affordable housing to close the gap in the market for young households is a problem. In the study in UK, young households are determined to be between 20 to 39 years old (Wilcox, 2003; 2006; 2008). This age of young households is considered as the breadth of first time home buyers. Wilcox (2008) argued that there is an Intermediate Housing Market (IHM) which is where households who are not eligible for housing benefits but cannot buy at the lowest decile of house price level in the housing market (see Figure 1.1). Ortalo-Magné and Rady (1999) observed co-movements of housing prices and owner occupancy rates and explained that there is an increasing rate of young households in homeownership because of the deregulation of the mortgage market which translated to easing the access to mortgage credit for young households. However, they concluded that decrease in interest rates alone is not the reason of increase owner occupancy rate among young households but also because of savings rate. 


\begin{tabular}{|c|c|c|c|c|}
\hline \multirow[b]{2}{*}{$\begin{array}{l}\text { Not in } \\
\text { work }\end{array}$} & \multicolumn{3}{|c|}{ Broad Intermediate Housing Market } & \multirow[b]{2}{*}{$\begin{array}{l}\text { Can buy } \\
\text { atLQ } \\
\text { level }\end{array}$} \\
\hline & $\begin{array}{l}\text { In work } \\
\text { but on } \\
\text { *HB }\end{array}$ & $\begin{array}{l}\text { Not on HB } \\
\text { but cannot } \\
\text { buy at *LD } \\
\text { level }\end{array}$ & $\begin{array}{l}\text { Cannot } \\
\text { buy at } \\
\text { *LQ } \\
\text { level }\end{array}$ & \\
\hline \multicolumn{5}{|c|}{ Narrow Intermediate Housing Market } \\
\hline
\end{tabular}

Figure 1.1: Intermediate Housing Market

Source: Wilcox (2008)

Additionally, the increasing demand of housing is caused by young households to find their own house and leave their parental homes (Green and Hendershott, 1996).Boehm and Schlottmann (1999) discovered that the average child of a homeowner is significantly more likely to achieve a higher level of education and thereby increases the likelihood that children will also become homeowners. They further argued that on average, parents who own homes are wealthier than those who rent and can provide financial help. This emphasizes financial help from parents who are homeowners capture an effect towards the problems of housing affordability among young households. However, Andrew et al. (2006) argued that young adults primarily choose to remain in their parental homes than private renting and owning a house.

In sum, there are many contributions to the housing affordability problem among young households. The problems are mainly in the scope of economy, social and political context. Furthermore, it is argued that young households are considered to be first time home buyers and are having problems in housing affordability. Although it is discussed that education has no connection to purchasing a house, the variable of education is important in perception of socio-economic status. Therefore, this paper aims to ascertain the housing affordability problems among young households in Greater Kuala Lumpur. The aim is supported with two objectives which are to identify the housing affordability problems among young households and to discuss the relationship between the identified problems. 


\section{HOUSING AFFORDABILITY PROBLEMS AMONG YOUNG HOUSEHOLDS}

Thalmann (2003) argued there are two potential affordability problems which are, if income minus the cost of standard housing consumption is no less than standard non-housing expenditure and if the cost of standard housing consumption does not exceed a given share of income. However, there are other problems in different perspectives as well. Having established the rationale for housing affordability problem especially among young households, the next issue to be considered is the three elements of what indicated and corresponded to housing affordability problems. The three key elements identified are house price, household income and housing choice.

\section{HOUSE PRICE}

House price plays an important role in housing affordability. Price is considered to be the most reliable index of housing market (Stutz and Kartman, 1982). Due to this important factor, it merits special attention especially in housing studies. Market forces and demand and supply indicates house price. Therefore, this warrants an outlook on what influence the housing market. According to Phang (2009), housing regulation has a housing market implication that includes expansion of the targeted housing sector over time, the relative constancy of actual housing expenditure to income ratios for targeted household groups, income inelastic housing demand and price inelastic housing supply. He argued that these forces are what drives the house price changes and are not relatively due to population growth rates and construction costs. In the context of this paper, when younger working households has the tendency to 'leave the nest' means there is greater demand of housing (Stutz and Kartman, 1982). The opportunist of the housing market who is either investors or speculators will send the house price upwards due to this increasing demand from younger households.

Apart from that, the availability of mortgage finance also increases demand in housing (Bredenoord and Verkoren, 2010). The changes in the quantity of housing demand will affect real prices only if the long-run housing supply is positive (Green and Hendershott, 1996). Supply side and demand side explanations for the decline of housing affordability are not mutually exclusive and does not lead to increase in house prices if housing demand is stable or declining (Matlack and Vigdor, 2008). In contrast, Mak et al. (2007) argued that demand and supply are interactive and tend to reinforce each other and while there is an increase in housing demand, the supply lags behind housing demand.

Rapid economic growth, increase in population, liberalization of the housing market and inadequate supply of affordable housing are the main reason behind the increase in house prices (Mak et al., 2007). House prices have increased markedly in many industrialized countries in recent years, apparently backing the strength of households' consumption in a context of otherwise weakening activity (Ayuso and Restoy, 2006). Apart from that, Lee (2009) discovered that the volatility of house price is subjected to rise in 
response to bad news and inflation is a determinant in housing price volatility. The housing price volatility also led to price discrimination in housing. As mentioned previously, young households are considered to be the victim of the house price game where the benefits are to those who are already homeowners and are older with more purchasing power than them. Ihlanfeldt and Mayock (2009) showed evidence that housing price discrimination exists in the housing market. Even so, prices of house are affected by bargaining skills and power of the buyers and sellers. Moreover, heterogeneous products such as a house and automobiles are typically trade in the market only in a single transaction.

Furthermore, there has been evidence of households in the lower tail of the income distribution is now less able to afford a house than they were a decade ago (Bajari et al., 2005; Matlack and Vigdor, 2008). With young households considerably to be at the lower tail of the income distribution, it questions if time would eventually decrease the housing affordability for the younger cohorts or otherwise. This is because when income growth is not in tandem with housing affordability (increase inflation), the increases in house price is good for homeowners who are selling their house but bad for households who are in the market to purchase a house (Stutz and Kartman, 1982; Bajari et al., 2005). Furthermore, severe housing problems are defined as a housing cost burden above 50 percent and occupying severely adequate units or both while moderate housing affordability problems involve a cost burden between 30 percent and 50 percent of income, occupying moderately inadequate units and overcrowding (Dolbeare, 2001). This intertwined problem of the house price as an affordability problem made it crucial in formulating an effective housing policy. It is the problem of inadequate cash flow in the short run and higher rents may present an affordability issue for tenants and younger working households in terms of housing prices (Stutz and Kartman, 1982).

\section{HOUSEHOLD INCOME}

In general, housing affordability is concerned with the relationship between housing costs and household income (Henman and Jones, 2012). There are a few perspectives in terms of the relationship between housing costs and household income. Yates (2008) for example, defined housing affordability problem as the result of housing costs for both purchasers and renters increasing faster than household income. The problem for household especially younger households is when living costs are perceived to be too high in relation to household income.

The perception of income is not enough to cover housing costs and non-housing expenditures are a problem in housing affordability. Maclennan and Williams (1990) suggested that affordability implies where the price of the house does not impose 'an unreasonable burden' on household income. In similar view, Stone (2006) argued that affordability is a challenge each household faced in balancing the housing costs and 
non-housing expenditures within the constraints of their income. The perception of imbalance of housing cost and non-housing expenditures clearly pose a problem that is related to households' income.

Apart from that, inequality in the distribution of income is a common problem in housing affordability. Matlack and Vigdor (2008) suggested that income increases at the high end of the distribution and can raise house prices paid by those at the low end of the income distribution. They further explained as income inequality grows the residual income of households' declines and crowding increases significantly. Younger households are considered to be between the low and middle end of the income distribution. This is because there are relatively young in the labor force market and earns a smaller scale in salary before gaining more working experiences. Bramley (2012) agreed with the problems to be more common with younger households due to lower incomes earlier in their work careers and limited asset accumulation and also their greater reliance on the private rented sector.

As discussed in previous sections, housing affordability problems among younger households are presented by inadequate cash flow. When the real required payments associated with homeownership increased rapidly over time, the financial challenge of purchasing housing is perceived to be more difficult (Rappaport, 2008). The uncertain income future posed a major limitation towards the ability to become home owners as well the subjectivity of economic success. Even more, what draws attention is whether housing cost or household income is the problem of housing affordability (Burke, 2007). However, housing choice also influence housing affordability problems.

\section{HOUSING CHOICE}

Housing choice is actions taken by households to decide on their choice of house. This includes tenure, type of house, location and neighborhood. The initial housing choice of younger households is either the preference of owning a house or rent. The tenure choice plays a significant role in understanding where younger households stand in housing affordability, of which, means that housing affordability in terms of purchasing or renting. In this context, housing affordability problems in housing choice is seen in the perspective of purchasing due to the framework on the right to housing and it is the state's duty to ensure household enjoy this right.

Once households have reached a considerably accepted socio-economic status, the choice of location of the house and neighborhood is important. Public houses are perceived for low income households and younger households are more likely to participate in private housing market (Fu et al., 2000). The quality of local public goods influence house price and this indicate that households care for the general upkeep of the neighborhood as well as the distant of schools and town centers (Kiel and Zabel, 2008). This influence the housing choice as well where younger households are looking for a similar neighborhood setting that is similar to where they grew up. 
Apart from that, Addae-Dapaah (1999) claimed that a house is more than a shelter with all the requisite amenities and represents an important status symbol and personal investment (cited in Tu et al., 2005). Due to this, housing choice is important to households. The question stands at how will choice in housing affects housing affordability among younger households. One problem will be to reject low cost houses and location that is near squatters. Additionally, when younger households desire to own a beautiful house that is larger in size and at prime location, they may choose to infringe residual income where they will risk material hardship (Bramley, 2012). Moreover, if housing choice does not met with what younger household desire, the household may live with others such as family and a large group of friends.

Another view of housing choice in financial perspective is when younger households are not capable to purchase a house of their desire, options similar to Employees Provident Fund (EPF) (in Malaysia) to pay off their mortgage loan and down payment. Even though, this enhanced homeownership among household, it presents a problem as well. Tu et al., (2005) deliberated that this present a problem when the household withdraw money from their Central Provident Fund (CPF) (in Singapore) accounts every month to pay mortgage loan repayment. This will caused households to have less money in their retirement savings which will adverse outcomes when households get older. According to Alexiu et al. (2010), there is a negative relationship between employment choice and housing preferences or affordability. This resulted to time consuming to travel to work place. This relationship shows that housing choice does not depend on work place and employment choice, rather due to other factors such as neighborhood characteristics as Kiel and Zabel (2008) concluded.

Bramley (2012) deliberated that younger households rely on the private rental sector. However, there is positive impact towards young homeowners in the society. Ihlanfeldt and Mayock, 2009) argued that young homeowners will generally improve race relations and will shaped racial attitudes. This positive impact of younger households towards homeownership will reflect less house price discrimination. However, Andrew et al. (2006) argued that younger households choose to remain in their parental house before private renting and lastly owning. In sum, this suggests that the housing affordability problem among younger households is an inter-related problem between house price, household income and housing choice.

\section{RESEARCH METHODOLOGY}

Measurable data is the primary concern of quantitative research approach (Neuman, 2006). Quantitative researchers approach their study deductively, strictly adhering practical measurements to the concept they established beforehand (Rameli, 2009). The data collected from quantitative approach is expressed in numbers in order to see the uniformity, intensity, quantity and frequency of response that is translated as the result of the findings. In this paper, the empirical materials are from face to face questionnaire survey. The main concern of the quantitative approach in this paper is to investigate the housing affordability 
problems among young households. The perception of the problems is from young households. The questionnaire survey is conducted in two months in 2013. The innate perceptions of young households are reckoned to be suitable to achieve the paper's aim.

The data from the questionnaire survey is analysed with the IBM SPSS software. A normality test was conducted before further analysis of the data. Due to the characteristics of parametric test and nonparametric test, this study analyse the data using the Mann-Whitney U test and Spearman correlation test (Chua, 2008). The questions on perceptions of housing affordability problems are based on 1 to 5 point Likert scale (Vagias, 2006). The level of agreement of the Likert scale is (1) for strongly disagree, (2) for disagree, (3) for neutral, (4) for agree and (5) for strongly agreed. The median of the ordinal scale score of the housing affordability problems perception is descriptive analysed to seek this relationship. Moreover, the correlation of this relationship is analysed by using the Spearman correlation test. This test is significant to determine different perceptions on housing affordability problems among house price, household income and housing choice.

\section{RESPONDENTS OF THE STUDY}

The sampling technique in this study is simple random sampling with pre-determined criteria. The sample size of the respondents is based on the population of young households (aged between 20 to 39 years old) in Greater Kuala Lumpur as reported by the Department of Statistics (2012) (see Table 1.1). The sample size was determined by Krejcie and Morgan's (1970) table of determining sample size. According to them, as the population increases, the sample size increases at a diminishing rate and remains relatively constant at slightly more than 380 cases. The total population of respondents aged 20 years old to 39 years old in GKL is 2,603,283 (Department of statistic, 2012). Based from the Krejcie and Morgan's (1970) table, the sample size is relatively constant at slightly more than 380 cases when the target population is more than $1,000,000$. Therefore, the total number of respondents in this paper is four hundred twenty $(\mathrm{N}=420)$ respondents.

Table 1.1 Population of young households in GKL by age group

\begin{tabular}{|l|c|}
\hline Local Authority in GKL & Number of population \\
\hline Putrajaya & 33,164 \\
\hline Kuala Lumpur & 623,828 \\
\hline Selayang & 215,399 \\
\hline Ampang Jaya & 192,761 \\
\hline Klang & 292,191 \\
\hline Shah Alam & 239,893 \\
\hline Petaling Jaya & 268,645 \\
\hline
\end{tabular}




\begin{tabular}{|l|c|}
\hline Subang Jaya & 317,251 \\
\hline Sepang & 90,439 \\
\hline Kajang & 329,712 \\
\hline Total & $\mathbf{2 , 6 0 3 , 2 8 3}$ \\
\hline
\end{tabular}

Source: Adapted from Department of Statistics (2012)

\section{QUESTIONNAIRE SURVEY}

The questionnaire survey was conducted with young households aged between 20 to 39 years old. The distribution was random with pre-requisite conditions which are, possessed a minimum of bachelor degree and currently working in GKL. The sample size is 420 respondents and the distribution is based on the population of young households in local authorities in GKL. The number of distribution for questionnaire survey is based on the percentage of young households' population by regions. For example, the central region consists of Kuala Lumpur, Petaling Jaya and Subang Jaya with the total amount of 1,209,724 young households' populations which accounts to 45 percent of the total young household's population in GKL. Therefore, 190 respondents are then based on the population within the local authorities in the region and resulted to the number of distribution in Table 1.2. The sampling was random and snowballing technique was applied whereby the respondents identify their acquaintances of the same targeted group to be potential respondents for this study.

Table 1.2: Number of distribution for questionnaire survey

\begin{tabular}{|l|c|}
\hline \multicolumn{1}{|c|}{ Local authority } & No. of distribution \\
\hline MP Selayang & 40 \\
\hline MP Ampang Jaya & 40 \\
\hline MP Kajang & 40 \\
\hline DB Kuala Lumpur & 90 \\
\hline MB Subang Jaya & 45 \\
\hline MB Petaling Jaya & 45 \\
\hline MB Shah Alam & 40 \\
\hline MP Klang & 40 \\
\hline Perbadanan Putrajaya & 20 \\
\hline MD Sepang & 20 \\
\hline Total & $\mathbf{4 2 0}$ \\
\hline
\end{tabular}

Source: Author

The questionnaire survey has 53 questions with an allocated time of less than 45 minutes per respondents. The questionnaire survey was self-administered. In this study, the questionnaire survey is conducted to seek 
perceptions on housing affordability problems. There are 5 parts in the questionnaire survey namely, Part A to Part E.

In part A, the respondent's profile is captured. This include, their age group which is either 20 to 24 years old, 25 to 29 years old, 30 to 34 years old and 35 to 39 years old, gender, ethnic, marital status and highest education level. This age group is chosen due to the definition of young households by Wilcox (2003; 2006; 2008) which is between 20 to 39 years old. The respondent's was also asked whether they are a homeowner or otherwise. For part B, the respondents were asked on their current employment background. The questions include their occupation, location of work place, current gross monthly salary and total years of working experience after graduation of Bachelor Degree. The focus of this part is to capture their working background including gross monthly income.

The focus of part $\mathrm{C}$ is to capture the total household income if the respondent is married. It will also capture employment background of spouse. For part D, the respondents answer questions on their current residence. This part described the current residence of the respondent in terms of location, type of house, period of living and also the best description of their current residence which are either own, rent, family residence or others. Consequently, there are two sub-parts whereby if the respondent owns the house, the respondent will answer what is the price of the house, how did they own the house and their monthly mortgage. If the respondents are currently renting, the respondents' are asked on their rental per month, other payments as a tenant and also on financial assistance to rent the house.

Lastly, part E obtained data on respondents' perception on housing affordability problems. This is divided into 5 themes which are housing affordability, housing price, household income, housing choice and housing policy and housing schemes. The survey managed to capture more than the target sample respondents with most respondents from Kuala Lumpur but only 420 respondents are selected in this study. No significant problems were encountered during the questionnaire survey.

\section{RESULTS AND DISCUSSION}

\section{HOUSE PRICE}

Based on the analysis, young households perceived house price as one of the contributor to the housing affordability problems. There are no significant difference in perceptions of house price as a housing affordability problem among young households in terms of age group, marital status, occupation and current residence (renting, lives with family or others). The analysis indicates that house price contributes to the housing affordability problems among young households. Firstly, young households perceived house piece as expensive for them to purchase and this is in accordance to their household income as argued by Wilcox (2007). Secondly, as Ayuso and Restoy (2006) discussed, young households are aware of 
overvaluation as a contribution towards this house price problem. Moreover, due to attract foreign investors private developers are focusing more on building high cost housing (Tan, 2011). Thus, this limits the housing purchasing power of young households as well as creating a bigger affordable housing gap in the housing market. Young households agreed with Lee (2009) on the volatility of house prices is what made it difficult for them to purchase a house.

\section{HOUSEHOLD INCOME}

In relation to the housing affordability problem of house price, household income also plays a role in purchasing a house. Due to this, household income is also considered as a housing affordability problem among young households. The findings demonstrated that household income does influence housing affordability problems. Based on the data analysis result of Mann-Whitney $U$ test, there are significant differences in perceptions of household income in terms of occupation between respondents who are selfemployed and private sector and gross monthly salary between respondents who earn RM 2,001 to RM 3,000 and respondents who earn RM 8,001 to RM 9,000.

The data analysis results of the Mann-Whitney $U$ test (see Table 1.3) reveal that there is a difference in perceptions on household income that is significant between respondents who earns RM 2,001 to RM 3,000 and respondents who earn RM 8,001 to RM 9,000 [p <.05]. The mean value of respondents who earn RM 2,001 to RM 3,000 (64.37) transcend respondents who earn RM 8,001 to RM 9,000 (9.50) that shows respondents who earn RM 2,001 to RM 3,000 in the population of this study experienced more problems in housing affordability. The box plot graph explained that the median value of respondents who earn RM 2,001 to RM 3,000 is higher as compared to the median value of respondent who earn RM 8,001 to RM 9,000. The box plot graph as in Figure 1.2 is in line with the result of the Mann-Whitney U test that respondents who earn RM 2,001 to RM 3,000 experienced more problems in housing affordability.

Table 1.3 Mann-Whitney U Test between household income and gross monthly salary

Test Statistics ${ }^{\mathrm{a}}$

\begin{tabular}{|l|r|}
\hline & $\begin{array}{l}\text { Household income } \\
\text { (RM 2,001-RM }\end{array}$ \\
& 3,000 and RM \\
& 8,001-RM 9,000) \\
\hline Mann-Whitney U & 16.000 \\
Wilcoxon W & 19.000 \\
Z & -2.119 \\
Asymp. Sig. (2- & .034 \\
tailed) & \\
Exact Sig. [2*(1- & $.021^{\mathrm{a}}$ \\
tailed Sig.) & \\
\hline
\end{tabular}

a. Not corrected for ties

b. Grouping Variable: Gross Monthly Salary Source: Questionnaire Survey (2012) 


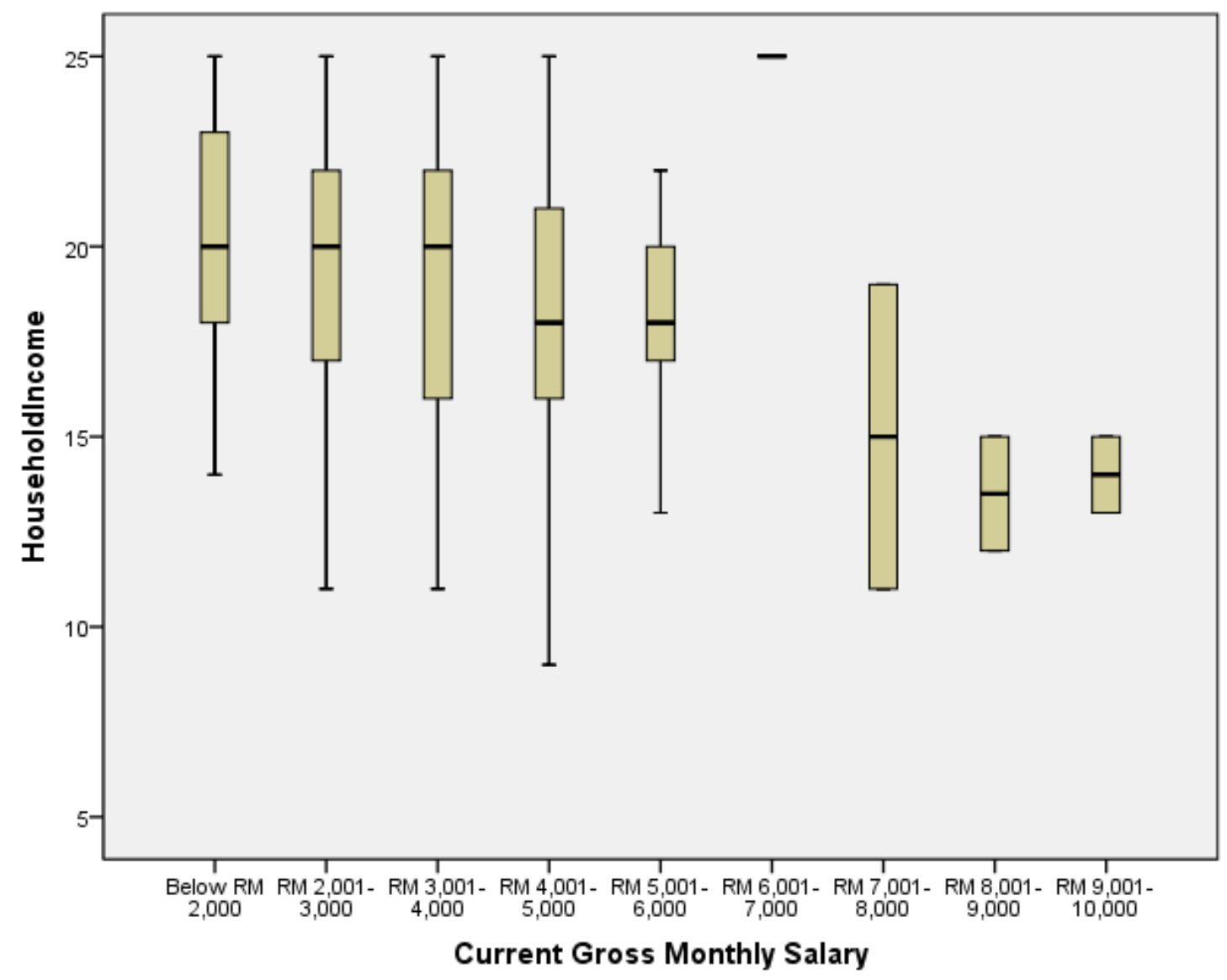

Figure 1.2: Box plot graph of perceptions on household income and gross monthly salary

Source: Questionnaire Survey (2012)

\section{HOUSING CHOICE}

Furthermore, it was argued that there is limited housing choice in the housing market for young households. This is considering their average current monthly income and average current house price in the market. Housing choice as a housing affordability problem is seen in three aspects which are the perception on the preference in terms of size and design and also choice of location. The majority (71.9\%) of the respondents agreed that design of the house plays a role in deciding to purchase an affordable house. Only 5.5 percent disagreed with this. Moreover, 42.1 percent of the respondents disagreed with purchasing an affordable smaller size house in an urban area. While 29.2 percent are undecided or neutral and 28.8 percent agreed. As for the perception on the location of the affordable house, 32.1 percent 'agree' and 14.0 'strongly agree' to bear transportation cost if the location is far from their work place while 31.4 percent are 
undecided and neutral. Accordingly, 16.6 percent 'disagreed' and 5.9 'strongly disagreed'. It is important to note that the percentage for the respondents who are undecided or neutral is similar to the percentage of 'agreed'. This shows that young households are between agreeing to not knowing which decision to make when it comes to if the location of a house they could afford is far from their workplace and involves a substantial amount of transportation cost.

Apart from that, the data analysis results of the Mann-Whitney U test reveal (see Table 1.4) that there is a difference in perceptions on housing choice that is significant between respondents who are renting and respondents who lives with family $[\mathrm{p}<.05]$. The mean value of respondents who are renting (151.64) exceed respondents who lives with family (117.72) that shows respondents who are renting in the population of this study experienced more problems in housing affordability.

Table 1.4 Mann-Whitney U Test between housing choice and current residence Test Statistics ${ }^{\mathrm{a}}$

\begin{tabular}{|l|r|}
\hline & $\begin{array}{l}\text { Housing choice } \\
\text { (Self-employed } \\
\text { and private } \\
\text { sector) }\end{array}$ \\
\hline Mann-Whitney U & 6366.000 \\
Wilcoxon W & 17541.000 \\
Z & -3.608 \\
Asymp. Sig. (2- & .000 \\
tailed) & \\
\hline
\end{tabular}

a. Grouping Variable: Current Residence

Source: Questionnaire Survey (2012)

There are two significant influence of housing choice as a housing affordability problem among young households. Firstly, in terms of size and design of the house, young households perceived that the market has not fulfilled their expectation of affordable housing in the market. Secondly, the location of affordable housing in the market plays a major role in housing affordability problems among young households. This indicates that young households could not afford a house in urban area that caused to burden themselves with transportation cost if they wish to become homeowners.

The data is analyzed using the Spearman correlation test. The test is used due to the ordinal scale of the data and is suitable to examine the correlation between the housing affordability problems (Chua, 2006). The analysis results of the Spearman correlation reveal that there is a moderate relationship that is significant between house price and household income in the housing affordability problems among young households $(\mathrm{r}=.60, \mathrm{p}<.05)$ (see Table 1.5$)$. The positive relationship shows that among young households, relatively, young households who have housing affordability problems in terms of house price 
will have problems in household income as well. Moreover, the analysis result of the Spearman correlation test between household income and housing choice shows a significant weak relationship in housing affordability problems among young households $(r=.343, \mathrm{p}<.05)$ (see Table 1.6). Similarly, the analysis result of the Spearman correlation test between housing choice and house price shows a significant weak relationship in housing affordability problems among young households $(r=.307, p<.05)$ (see Table 1.7). Above all, the analysis and discussion of the Likert scale underline that the housing affordability problem is house price, household income and housing choice which are separate problems but are interrelated.

Table 1.5: Spearman correlation test between house price and household income

\section{Correlations}

\begin{tabular}{|l|l|l|l|l|}
\hline & & & House Price & Household Income \\
\hline & & $\begin{array}{l}\text { Correlation } \\
\text { Coefficient }\end{array}$ & 1.000 & $.600^{* *}$ \\
\hline & House Price & Sig. (2-tailed) &. & .000 \\
\hline Spearman's rho & & $\mathrm{N}$ & 271 & 271 \\
\hline & & $\begin{array}{l}\text { Correlation } \\
\text { Coefficient }\end{array}$ & $.600^{* *}$ & 1.000 \\
\hline & Household Income & Sig. (2-tailed) & .000 &. \\
\hline & & $\mathrm{N}$ & 271 & 271 \\
\hline
\end{tabular}

**. Correlation is significant at the 0.01 level (2-tailed)

Source: Questionnaire Survey (2012)

Table 1.6: Spearman correlation test between household income and housing choice

\section{Correlations}

\begin{tabular}{|l|l|l|l|l|}
\hline & & & Household Income & Housing Choice \\
\hline & & $\begin{array}{l}\text { Correlation } \\
\text { Coefficient }\end{array}$ & 1.000 & $.343^{* *}$ \\
\hline & House Income & Sig. (2-tailed) &. & .000 \\
\hline Spearman's rho & & $\mathrm{N}$ & 271 & 271 \\
\hline & & $\begin{array}{l}\text { Correlation } \\
\text { Coefficient }\end{array}$ & $.343^{* *}$ & 1.000 \\
\hline & Housing Choice & Sig. (2-tailed) & .000 &. \\
\hline & & $\mathrm{N}$ & 271 & 271 \\
\hline
\end{tabular}

**. Correlation is significant at the 0.01 level (2-tailed)

Source: Questionnaire Survey (2012) 
Table 1.7: Spearman correlation test between housing choice and house price

\section{Correlations}

\begin{tabular}{|l|l|l|l|l|}
\hline & & & Housing Choice & House Price \\
\hline & & $\begin{array}{l}\text { Correlation } \\
\text { Coefficient }\end{array}$ & 1.000 & $.307^{* *}$ \\
\hline & Housing Choice & Sig. (2-tailed) & $\cdot$ & .000 \\
\hline Spearman's rho & & $\mathrm{N}$ & 271 & 271 \\
\hline & & $\begin{array}{l}\text { Correlation } \\
\text { Coefficient }\end{array}$ & $.307^{* *}$ & 1.000 \\
\hline & House Price & Sig. (2-tailed) & .000 &. \\
\hline & & $\mathrm{N}$ & 271 & 271 \\
\hline
\end{tabular}

**. Correlation is significant at the 0.01 level (2-tailed)

Source: Questionnaire Survey (2012)

Young households perceived a number of attributes has resulted to this housing affordability problem. The attributes include inadequate cash flow, insufficient affordable housing supply and housing preferences ensued to their capability to afford their first house. This is in line with Thalmann (2003) who perceived houses as affordable if the income spent on housing crowds out other non-housing expenditures. Furthermore, even if there are houses that are affordable to young households within their work place, the supply of houses are limited (Wan et. al, 2010). The analysis also shows that the problems with affordability are not only focused on household income and housing supply but on housing choice as well (Bajari et al., 2005).

\section{CONCLUSION}

The housing affordability problems among young households are attributes of house price, household income and housing choice in the housing market. The empirical evidence clearly determined that these are three separate but inter-related problems. The problem of insufficient income to purchase a house relates to house price that is not affordable for young households. Even more, there is limited housing choice in the supply of affordable housing in the housing market. Therefore, the role of state in this problem is important especially in closing the gap of supplying affordable housing in the housing market.

Due to these problems, state intervention is crucial. The main aim of the housing policy is to ensure every household enjoy their housing right to own adequate housing. In general, the derivatives of the housing affordability problems among young households are in the perspective of intervention by the state can be divided into three categories, which are, housing production in terms of housing supply, housing exchange in terms of buying or renting a house and housing consumption in terms of household purchasing capability 
(Milligan, 2003). This is closely related to the housing affordability problems among young households which are influenced by house price, household income and housing choice in the housing market. The intervention by the state in these categories will ensure housing affordability problems are kept at a minimum level. This study emphasize of the gap of affordable housing for young households in the market where they have to compete with all income groups. This led to young households losing out on affordable housing in the market because of the one primary and significant factor which is household income of young households is smaller in scale as compared to older cohort members of the middle income household. Even though house prices are increasing at a slow rate especially in GKL (NAPIC, 2012), state intervention is crucial. While the private market is favorable for a flourishing economy, the main aim of the housing policy is that every household should have adequate housing. As mentioned before, intervention by the state can be distinguished in three main aspects which are housing production, housing exchange and housing consumption. The state has responded through housing policy and subsidized housing scheme in order to cope with this housing affordability problem. However, these interventions by the state are not holistic in the three main aspects and are not in tune to a smoother solution towards housing affordability problems. The missing aspect of the state intervention draws a gap in housing affordability problem in terms of affordable housing for young households.

In sum, the findings revealed that the main problem faced by young households is limited supply of affordable housing in the market. This is attributed to key problems of house price, household income and housing choice in the housing market faced by young households. These affordable housing are yet to be fulfilled by the market (Abdul Rahman, 2013). Even more, the perceived affordable housing in the market is open to all income groups which suggest that young households has to compete with other income groups in the open market for homeownership. The state has to a certain degree intervened in the market by introducing NHP, MFHS and PR1MA to assist in housing affordability problems among young households. However, the role of PR1MA and MFHS is yet to be measured. Moreover, this intervention is viewed as insufficient. This is because the state has only intervened in housing production and housing exchange but there is less intervention in housing consumption. It is important for the state to intervene in housing consumption as the housing affordability problems among young households encompass decreasing purchasing power capability in the housing market. Furthermore, it is also recommended that state should perhaps consider properties to be rented that are affordable to young households. However, caution should be taken by the state to not impose similar layout of low cost rental housing for young households due to the socio-economic status of middle income households. 


\section{REFERENCES}

Abdul Rahman, E. (2013). Responding to the Globalization and the State: Negotiations and Contestation by the Middle Class in Malaysia. Globalization and Social Transformation in the Asia-Pacific: The Australian and Malaysian Experience. C. Tazreiter and S. Y. Tham, Palgrave Macmillan.

Alexiu, T. M., et al. (2010). "Impact of education in terms of housing opportunities." Procedia - Social and Behavioral Sciences 2(2): 1321-1325.

Andrew, M., et al. (2006). "Explaining the route to owner-occupation: A transatlantic comparison." Journal of Housing Economics 15(3): 189-216.

Ayuso, J. and F. Restoy (2006). "House prices and rents: An equilibrium asset pricing approach." Journal of Empirical Finance 13(3): 371-388.

Bajari, P., et al. (2005). "House prices and consumer welfare." Journal of Urban Economics 58(3): 474487.

Beltratti, A. and C. Morana (2010). "International house prices and macroeconomic fluctuations." Journal of Banking \& Finance 34(3): 533-545.

Boehm, T. P. and A. M. Schlottmann (1999). "Does Home Ownership by Parents Have an Economic Impact on Their Children?" Journal of Housing Economics 8(3): 217-232.

Bramley, G. (2012). "Affordability, Poverty and Housing Need: Triangulating Measures and Standards." Journal of Housing and the Built Environment 27(2): 133-151.

Bredenoord, J. and O. Verkoren (2010). "Between self-help - and institutional housing: A bird's eye view of Mexico's housing production for low and (lower) middle-income groups." Habitat International 34(3): 359-365.

Burke, T. (2007). "Experiencing the Housing Affordability Problem: Blocked Aspirations, Trade-offs and Financial Hardships." Financial Review Housing Congress.

Chua, Y. P. (2008). Asas Statistik Penyelidikan: Analisi data skala ordinal and skala nominal (Vol. 3). Malaysia: McGraw-Hill.

Department of Statistics (2012). Household Income Survey. Kuala Lumpur.

Dolbeare, C. N. (2001). "Housing affordability: Challenge and context." Cityscape: 111-130.

$\mathrm{Fu}$, Y., et al. (2000). "Housing choice behavior of urban workers in China's transition to a housing market." Journal of Urban Economics 47(1): 61-87. 
Green, R. and P. H. Hendershott (1996). "Age, housing demand, and real house prices." Regional Science and Urban Economics 26(5): 465-480.

Henman, P. and A. Jones (2012). Exploring the use of residual measures of housing affordability in Australia: methodologies and concepts. AHURI Final Report No. 180. A. Badenhorst, Australian Housing and Urban Research Insititute

Ihlanfeldt, K. and T. Mayock (2009). "Price discrimination in the housing market." Journal of Urban Economics 66(2): 125-140.

Kiel, K. A. and J. E. Zabel (2008). "Location, location, location: The 3L Approach to house price determination." Journal of Housing Economics 17(2): 175-190.

Krejcie, R. V. and D. W. Morgan (1970). "Determining sample size for research activities." Educational and psychological measurement 30(3): 607-610.

Lee, C. L. (2009). "Housing price volatility and its determinants." International Journal of Housing arkets and Analysis 2(3): 293-308.

Maclennan, D. and P. Williams (1990). Affordable Housing in Britain and America. York, Joseph Rowntree Foundation.

Mak, S. W. K., et al. (2007). "Privatization, housing conditions and affordability in the People's Republic of China." Habitat International 31(2): 177-192.

Matlack, J. L. and J. L. Vigdor (2008). "Do rising tides lift all prices? Income inequality and housing affordability." Journal of Housing Economics 17(3): 212-224.

Milligan, V. R. (2003). "How different? Comparing housing policies and housing affordability consequences for low income households in Australia and the Netherlands."

NAPIC (2012). [Property Market Report].

Neuman, W. (2006). Social Research Methods: Qualitative and Quantitative Approaches, Pearson Education, Inc., London.

Ortalo-Magné, F. and S. Rady (1999). "Boom in, bust out: Young households and the housing price cycle." European Economic Review 43(4-6): 755-766.

Phang, S.-Y. (2009). Affordable homeownership policy: implications for housing markets and housing elasticities. European Real Estate Society Conference. Stockholm.

Rameli, A. (2009). Land Use Planning System And Housing Development

Process In Malaysia. Urban and Regional Planning, Universiti Teknologi Malaysia. 
Rappaport, J. (2008). "The Affordability of Homeownership to Middle-Income Amercians." Economic Review 4.

Stutz, F. P. and A. E. Kartman (1982). "Housing Affordability and Spatial Price Variations in the United States." Economic Geography 58(3): 221-235.

Tan, T.-H. (2011). "Meeting first-time buyers' housing needs and preferences in greater Kuala Lumpur." Cities.

Thalmann, P. (2003). "'House poor' or simply `poor'?" Journal of Housing Economics 12(4): 291-317.

Tu, Y., et al. (2005). "An empirical analysis of Singapore households' upgrading mobility behaviour: from public homeownership to private homeownership." Habitat International 29(3): 511-525.

Vagias, W. M. (2006). Likert-type scale response anchors. Clemson International Institute for Tourism and Research Development, 1.

Wan, N. A., et al. (2010). Housing affordability issues for middle income households: The Malaysian perspective. 22nd International Housing Research Conference. Istanbul.

Wilcox, S. (2003). Can work - Can't buy. Local measures of the ability of working households to become home owners. UK, Joseph Rowntree Foundation.

Wilcox, S. (2006). The geography of affordable and unaffordable housing. York, Joseph Rowntree Foundation.

Yates, J. (2008). "Australia's housing affordability crisis." Australian Economic Review 41(2): 200-214. 